[3] C. B. Willingham and F. D. Rossini, J. Research NBS 37, 15 (1946) RP1724.

[4] A. J. Streiff, J. C. Zimmerman, L. F. Soule, M. T. Butt, V. A. Sedlak, C. B. Willingham, and F. D. Rossini, J. Research NBS 41, 323 (1948) RP1929.

[5] A. F. Forziati, J. Research NBS 44, 373 (1950) RP2085.

[6] M. R. Fenske, Ind. Eng. Chem. 24, 482 (1932).

[7] M. R. Fenske, Science of Petroleum, II, 1629. (Oxford Univ. Press, London, 1938).

[8] A. F. Forziati, C. B. Willingham, B. J. Mair, and F. D. Rossini, J. Research NBS 32, 11 (1944) RP1571.

[9] A. F. Forziati and F. D. Rossini, J. Research NBS 39, 425 (1947) RP1839.
[10] A. F. Forziati, W. R. Norris, and F. D. Rossini, J. Research NBS 43, 555 (1949) RP2049.

[11] American Petroleum Institute Research Project 44. National Bureau of Standards. Catalog of Infrared Spectral Data, Serial No. 326, 1,2-diethylbenzene, contributed by the Socony Vacuum Oil Co., and Serial Nos. 331, 332, 333 for the three isomers of diethylbenzene, contributed by the Anglo-Iranian Oil Co.

Washington, June 1, 1950.

\title{
Aging of Karakul and Seal Fur Skins
}

\author{
By Edward T. Steiner and Elizabeth R. Hosterman
}

\begin{abstract}
Physical and chemical data are presented for two types of fur skins of widely different dressings and characteristics to show that deterioration takes place when furs are stored under conditions considered noninjurious. There occur during storage an appreciable loss of strength amounting to as much as 25 to 40 percent, and a change in certain chemical properties. Pelts weakened by aging showed increased soluble nitrogen and water extractives and lower grease contents (petroleum ether extractives) than less aged skins. A fair correlation exists between the observed changes in chemical and physical properties. The presence and quantity of copper in the weakened pelts offer the only reasonable explanation for the cause and the extent of the deterioration.
\end{abstract}

\section{Introduction}

The value of dressed fur skins used annually in this country is estimated at several hundred million dollars. The more than moderate investment that is required in the purchase of fur garments does not always seem to be commensurate with the expected 2- to 10-year service life of most furs. By contrast, properly tanned leather may be expected to last from 10 to 40 years when not subjected to severe abrasion or chemical action. If the causes for the relatively short life span of the processed furs could be discovered and eliminated, there would result considerable economic advantage to the consumer, the distributor, and the manufacturer.

Various reasons have been offered for the relatively poor wearing qualities of fur garments. In the first place, the skins from most fur animals are naturally weak. Secondly, the procedures for dressing the skins are not so highly developed as those for making leather, primarily because of the purposes for which the furs are intended. In straight leather making, removal of the hair is required. The process of removing it tends to give better quality leather. With furs, the hair, of course, must be left on. Certain chemicals and tanning agents suitable for leather manufacture adversely affect fur quality and appearance, and cannot be used for fur dressing. It is the aim of fur dressers to keep the weight of the dressed pelts light, while the leather manufacturer usually strives to give weight to his product.

Carelessness on the part of the consumer is often responsible for the poor service given by furs. Improper drying after exposure to the elements, faulty cleaning methods, and storage in polluted atmospheres materially shorten the life of fabricated furs.
Such factors, however, do not account for the loss of strength of furs that have never been exposed to such conditions. Fur skins frequently become weak with age, apparently without cause.

The source of the deterioration is not apparent because the leather is concealed from view between the hair of the fur and the lining of the garment. The present work was undertaken to investigate the possible causes and extent of deterioration occurring in fur skins stored under conditions that would not be expected to cause losses of strength.

The Government's interest in furs centers about a protective and advisory role. It wishes to assist and cooperate in helping to bring about maintenance of a constant supply of fur animals, whether they be wild or captive. Through its agency, the Fish and Wildlife Service, Department of Interior, the Government compiles results of surveys of state agencies on the stock of various species and enacts legislation based on these statistics, regarding the "take" of the animals, in order to provide a balance between supply and preservation. Through another of its agencies, the Fur Farming Investigations, of the Department of Agriculture, economical methods of feeding, breeding, and management of fur animals in captivity are studied.

Examples of the work the Government has been doing along these lines include supervision of the annual catch of Alaskan fur seals off the Pribilof Islands and experimentation in the breeding of Karakul sheep.

Alaskan seal furs are furs of distinction and importance in the industry. By far the world's largest supply comes from the Pribilof Islands off the coast of Alaska. Until 1910 pelagic sealing, which means the killing of seals in water, almost resulted in the 
extinction of the herd. Through the efforts of this country, a treaty that prohibited the pelagic sealing operations was drawn up between the United States and other sealing countries. Fur sealing operations are now directly under the control of the Federal Government, and as a result the herd has grown from a state of near depletion to about $3,000,000$. Each year the Government, after estimating the number of animals, specifies how many seals may be taken from the herd for fur purposes. The killing is made under Federal supervision, after which the skins are shipped inland, processed under Government contract, and sold at public auction. The income from the seal industry to date has netted the United States approximately $\$ 100,000,000$.

Karakul type lambs are valuable in the manufacture of fur coats and fur-trimmed garments. Since importation of the live animals from countries in which the breed is being grown is prohibited by legal restrictions, because of serious diseases of the animals, multiplication in this country must be through breeding and cross-mating of Karakuls.

Since 1928 the Bureau of Animal Industry, U. S. Department of Agriculture, has been conducting cross-breeding experiments in which Karakul rams have been mated with ewes of the more available American types. The purpose of the cross-breeding is to compare the quality of fur produced thereby with fur produced on purebred Karakuls. The value of the yearly crops of the resultant skins is judged for that Bureau by appraisers in the Persian lamb fur industry, after which the skins are dressed according to commercial procedures.

\section{Description of the Furs}

The Alaskan seal furs were used as standards of comparison in 1939 in evaluating tannages of various bidders in connection with contract awards for the dressing of the Government's annual take of seals from the Pribilof Islands. Replicate samples of the standards were stored under conditions generally considered satisfactory for preservation, in the National Bureau of Standards leather laboratory, for 10 years. A limited number of properties were studied in 1939; the same tests were repeated on the storage samples in 1949. Some of the results were found suitable for comparison with those obtained on the lambskins.

Case histories of the seal furs are not known. Each pelt appeared to be of good quality, the skin being dressed by an oil process, and the fur dyed either an attractive brown or black shade.

A limited number of the dressed lambskins were made available to this Bureau through the courtesy of the Bureau of Animal Industry, as a part of a cooperative project relative to investigations on the effect of dressing procedures and other factors on the strength and durability of fur skins.

The Karakul pelts are excellent subjects for investigation, because of the wide age range of from 3 to 20 years. Unfortunately, information concerning the freshly processed skins is not available. In studying aging effect, certain physical and chemical

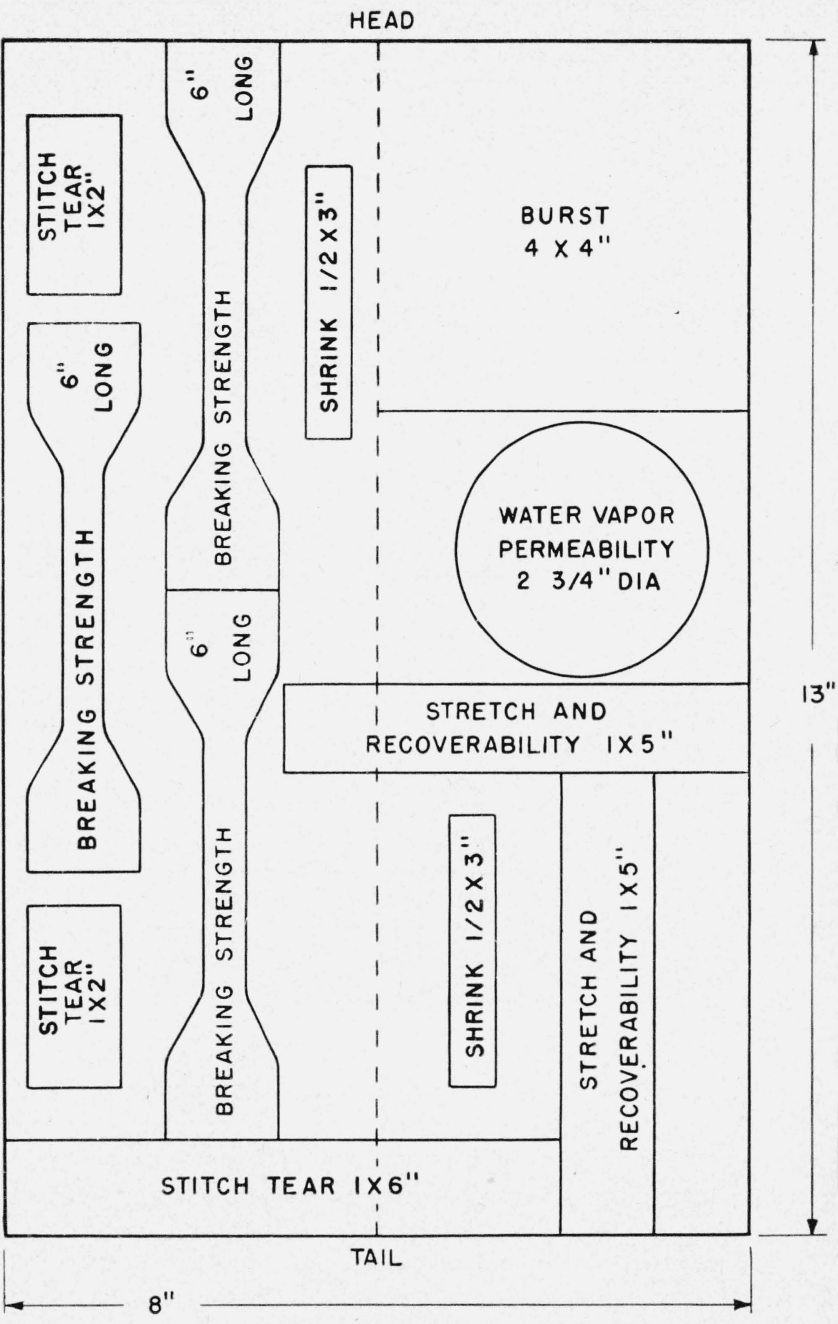

FIGURE 1. Location of test pieces for physical tests on lambskins.

properties of the fur skins can be defined that are indicative of the changes that take place as the storage period of the skins increases.

Specimens of the lambskins, representative of the yearly crops of $1929,1930,1931,1932,1933,1944$, 1945 , and 1946 , were submitted. The number of skins available did not permit sampling an equal number for each year group. In addition, pelts within a year were composed of purebreds and crossbreds, and it was necessary to observe whether aging qualities of purebred Karakuls differed from those that were crossbred. Specimens of each group were selected for physical tests in accordance with the scheme shown in figure 1. Remnants from the physical test pieces, as well as the remainder of the pelts from which they were cut, were ground to serve as samples for chemical tests.

\section{Effect of Crossbreeding in Relation to Strength of Karakul Pelts}

A comparative study of the effect of breeding was made on three skins of 100-percent Karakul, and on three skins of 50-percent Karakul, for the years 1930, 
1931, and 1932. Breaking strength and stitch tear A values were determined in accordance with the methods outlined in Federal Specification $\mathrm{KK}-\mathrm{L}-311$, Leather and Leather Products; General Specifications (Methods of Sampling, Inspection, and Tests).

Stitch tear B specimens were prepared in the following manner. The two free ends of the 1by 5 -in. specimens were sewn together by a local furrier who used equipment and technique of the industry. The resultant loop was then cut with scissors so that the stitched seam was in the center of the specimen. The ends were then placed in the jaws of a tensile testing machine, and the force required to pull the stitchings through the leather was measured.

Burst values were obtained on equipment modified for testing leather by Bureau personnel. The apparatus fastens to the cage used in compression measurements on a machine of the Tinius Olsen Electromatic Tester type. The principle is essentially the same as for the usual Mullen burst tester, except that the plunger is entirely metal and of smaller diameter than the Mullen's rubber diaphragm. The modified equipment has greater testing capacity than the Mullen and is capable of testing leathers of high stretch values. The plunger was forced against the flesh side of the leather.

The average values for the physical properties of the two breeds are shown in table 1, for the years specified.

TABLE 1. Comparison of strength and purity of breed of aged Karakul pelts

\begin{tabular}{|c|c|c|c|c|}
\hline \multirow{2}{*}{ Test } & \multicolumn{3}{|c|}{ Year of crop } & \multirow{2}{*}{$\begin{array}{c}\text { Purity of } \\
\text { breed }\end{array}$} \\
\hline & 1930 & 1931 & 1932 & \\
\hline $\begin{array}{l}\text { Breaking strength (lb/1/2-in.-wide } \\
\text { strip) } \\
\text { Stitch tear A (lb) } \\
\text { Stitch tear B (lb) } \\
\text { Burst (lb) }\end{array}$ & $\begin{array}{r}22.3 \\
15.6 \\
5.9 \\
4.4 \\
3.9 \\
5.2 \\
88.0 \\
65.0\end{array}$ & $\begin{array}{r}26.4 \\
20.5 \\
8.6 \\
5.9 \\
9.4 \\
6.0 \\
105.0 \\
86.0\end{array}$ & $\begin{array}{r}23.0 \\
12.6 \\
6.8 \\
4.6 \\
6.0 \\
3.4 \\
112.0 \\
53.0\end{array}$ & $\begin{array}{r}\text { Percent } \\
100 \\
50 \\
100 \\
50 \\
100 \\
50 \\
100 \\
50\end{array}$ \\
\hline
\end{tabular}

The results show that, on the average, the difference of each physical property between the two purities of breed is greater than that which occurs or can be accounted for in the measurement of the individual specimens within a breed.

The data show highly significant differences due to breed at the 1-percent level for the first two properties listed, and differences significant at the 5-percent level for the stitch tear B and burst values. Significance at the 1-percent level means that if no real difference existed, then a difference as large as that observed or larger would occur only once in a hundred times on the average. Significance at the 5percent level means that if no real difference existed, then a difference as large as that observed, or larger, would occur only five times in a hundred times on the average. Therefore, one can assume that a real difference exists between the two breed types of sheep and that the degree of confidence one can have in the difference, as represented by the results of the various tests, is greater for the tests of 1-percent significance than those of 5-percent significance.

In finding the aging effect within a breed, only the 100-percent Karakuls were studied. Sufficient specimens of the 50-percent crossbred type were not available for similar comparison.

\section{Physical and Chemical Properties of the Furs}

The physical properties of the 100-percent Karakul skins for various years of age are shown in table 2 .

All of the determinations were made on test pieces with the fur on, as it is practically impossible to remove the fur without damaging the test pieces. Efforts to remove the hair by means of clippers, electric razors, buffing, and the like were unsuccessful, and the results of the strength data are expressed, therefore, without regard to thickness.

There is no evidence of yearly or gradual changes in physical properties, particularly strength, during the storage periods. However, if the skins of 1930 , 1931, 1932, and 1933 are grouped and compared, with the skins of 1945 and 1946 considered as another group, significant differences are indicated insofar as breaking strength, furrier sewn-stitch tear (B), and burst values are concerned.

TABLE 2. Physical properties of aged 100 percent Karakul fur skins

\begin{tabular}{|c|c|c|c|c|c|c|}
\hline \multirow{3}{*}{ Property } & \multicolumn{6}{|c|}{ Year of crop } \\
\hline & \multicolumn{4}{|c|}{ Group I } & \multicolumn{2}{|c|}{ Group II } \\
\hline & 1930 & 1931 & 1932 & 1933 & 1945 & 1946 \\
\hline Breaking strength (lb). & 22.3 & 26.4 & 23.0 & 19.3 & 38.2 & 33.5 \\
\hline Stretch at break (lb). & 31.3 & 37.0 & 31.2 & 35.9 & 37.2 & 32.4 \\
\hline Stitch tear A (lb) & 5.9 & 8.6 & 6.8 & 7.4 & 6.6 & 6.2 \\
\hline Stitch tear B (lb). & 3.9 & 9.4 & 6. 0 & 9.4 & 13.5 & 14.1 \\
\hline Burst (lb) & 88.0 & 105.3 & 112.0 & 89.0 & 205. 3 & 142.0 \\
\hline Water vapor permeability ( $\mathrm{mg} / \mathrm{min}$ ) & 4.5 & 4. 9 & 5. 0 & 5.4 & 4.6 & 4.5 \\
\hline $\begin{array}{l}\text { Resilience coefficient (parallel to back- } \\
\text { bone) }\end{array}$ & 0.24 & 0.26 & 0.22 & 0.26 & 0.24 & 0.21 \\
\hline Shrink temperature $\left({ }^{\circ} \mathrm{C}\right)$ & $\begin{array}{l}0.24 \\
55.8\end{array}$ & $53.7^{0}$ & $\begin{array}{l}0.22 \\
48.7\end{array}$ & 49.0 & 52.7 & 54.0 \\
\hline
\end{tabular}

A comparison of data in groups I and II indicates that there has been loss in strength of the lambskins during the longer storage periods.

On the assumption that the loss of strength is caused by a decomposition process, the six age groups were examined chemically. The constituents of the skins determined were moisture, grease (petroleum ether extract), total and insoluble ash, water solubles, and total and soluble nitrogen. The results are tabulated in table 3 , on a dry combined leather and hair basis. The same difficulty in removing the hair from the chemical test specimens was experienced as with the physical test pieces. The incompleteness with which the fibers could be removed from the grain, and the uncertainty of how much remained within the grain after clipping or shearing, prompted the decision to sample the whole pelt for the comparative chemical analysis. 
TABLE 3. Chemical constituents of the yearly crops-100percent Karakul

\begin{tabular}{|c|c|c|c|c|c|c|}
\hline \multirow{3}{*}{ Constituent } & \multicolumn{6}{|c|}{ Year of crop } \\
\hline & \multicolumn{4}{|c|}{ Group I } & \multicolumn{2}{|c|}{ Group II } \\
\hline & 1930 & 1931 & 1932 & 1933 & 1945 & 1946 \\
\hline $\begin{array}{l}\text { Grease (dry) } \\
\text { Ash, total (dry) } \\
\text { Ash, insoluble (dry) } \\
\text { Water solubles (dry) } \\
\text { Protein, total (dry) } \\
\text { Protein, soluble (dry) } \\
\text { pH }\end{array}$ & $\begin{array}{r}\text { Percent } \\
6.97 \\
5.60 \\
2.10 \\
12.12 \\
75.42 \\
4.67 \\
3.5\end{array}$ & $\begin{array}{r}\text { Percent } \\
6.27 \\
6.64 \\
2.79 \\
9.89 \\
74.80 \\
3.15 \\
3.5\end{array}$ & $\begin{array}{r}\text { Percent } \\
9.65 \\
6.70 \\
2.20 \\
10.34 \\
68.73 \\
4.10 \\
3.5\end{array}$ & $\begin{array}{c}\text { Percent } \\
8.41 \\
4.07 \\
2.02 \\
8.92 \\
72.78 \\
3.48 \\
3.4\end{array}$ & $\begin{array}{r}\text { Percent } \\
10.55 \\
5.52 \\
2.31 \\
5.60 \\
69.74 \\
1.24 \\
3.3\end{array}$ & $\begin{array}{r}\text { Percent } \\
10.27 \\
5.51 \\
1.98 \\
6.53 \\
71.15 \\
1.18 \\
3.4\end{array}$ \\
\hline
\end{tabular}

s Petroleum ether extract.

Although the percentage of hair or wool may vary from pelt to pelt, the procedure of including the hair in the examinations is probably no less accurate than one using samples from which the hair had been only partially removed. The factor 5.62 is used to convert the nitrogen value to protein.

As in the data for the physical properties, there seems to be no yearly or gradual change in chemical properties. If, however, the skins are again grouped and compared as follows: 1930, 1931, 1932, 1933 versus 1945 and 1946, significant differences are noted in the grease (petroleum ether extract), water solubles, and soluble protein of those two groups.

The amounts of grease extracted with petroleum ether are lower for the more aged skins. It is possible that some of the grease in the skins has volatilized during the long storage periods, but it is also possible that some free oils in the pelts have oxidized during the years of aging. The oxidized oils would not be recoverable by the petrolic solvent and would therefore appear as apparent losses of grease. Compared with group II, group I pelts show an approximately 25 percent lower petroleum ether extractive value. Using the same solvent, black and brown seal furs showed, respectively, reductions of 11.5 and 14.1 percent of their original grease contents.

In contrast to the "lower" grease content in the lambskins, the water soluble contents are higher for the more aged skins. This is to be expected, for if a deterioration is occurring it should be reflected in a higher proportion of water solubles, as soluble nitrogenous decomposition products are found in the water solubles.

Summation, on a dry basis, of the total protein value, grease, insoluble ash, and water solubles accounts fairly well for the total composition of the skins. The composition accounted for by the addition of these items, for the year groups, is as follows:

\begin{tabular}{|c|c|c|c|}
\hline Year & $\begin{array}{l}\text { Percent- } \\
\text { age }\end{array}$ & Year & $\begin{array}{l}\text { Percent- } \\
\text { age }\end{array}$ \\
\hline 1930 & 96.6 & 1933 & 92.1 \\
\hline 1931 & 93. 7 & $1945_{-}$ & 88.2 \\
\hline 1932 _ & 90.2 & 1946 & 89.9 \\
\hline
\end{tabular}

One-hundred-percent recovery is not expected since these skins are predominantly alum-tanned. The methods of analysis provide no means of accounting for all the components of the skins. It appears that as deterioration proceeds there occurs a breakdown of the mineral complex, which is reflected in the water solubles value. High water soluble values relate well with low residual strengths remaining in the skins. Not only are soluble nitrogenous decomposition products found in the water solubles, but other organic matter as well. If the water soluble values are corrected for soluble ash, and the remainder considered as organic matter, the latter correlate inversely with strength values. In table 4 are shown the calculated values of the residual organic matter compared with burst values.

TABle 4. Relation of soluble organic matter to burst values

\begin{tabular}{|c|c|c|c|c|c|}
\hline Year & $\begin{array}{c}\text { Organic } \\
\text { matter } \\
\text { (calculated) }\end{array}$ & Burst & Year & $\begin{array}{c}\text { Organic } \\
\text { matter } \\
\text { (calculated) }\end{array}$ & Burst \\
\hline $\begin{array}{l}1930 \ldots \\
1931 \ldots \\
1932 \ldots\end{array}$ & $\begin{array}{r}\text { Percent } \\
8.62 \\
6.04 \\
5.84\end{array}$ & $\begin{array}{r}88 \\
105 \\
112\end{array}$ & $\begin{array}{l}1933 \ldots \\
1945 \ldots \\
1946 \ldots\end{array}$ & $\begin{array}{r}\text { Percent } \\
6.87 \\
2.39 \\
3.00\end{array}$ & $\begin{array}{r}89 \\
205 \\
142\end{array}$ \\
\hline
\end{tabular}

The correlation may be fortuitous, but these two properties certainly appear worthy of inclusion in observing changes occurring in aging fur skins.

The results of $\mathrm{pH}$ determinations on the lambskins preclude the possibility that the skins deteriorated because of red rot. The $\mathrm{pH}$ values lie in a range considered safe for leather preservation. Similarly, $\mathrm{pH}$ values of 3.5 and 3.0 , obtained respectively for the black and brown seal furs after 10 years storage show that they are not dangerously acid.

Sulfur values, expressed for simplicity as $\mathrm{BaSO}_{4}$, for the two age groups of the lambskins are:

$\begin{array}{ccc} & \begin{array}{c}1930 \text { to } 1933 \\ \%\end{array} & \begin{array}{c}1945 \text { and } 1946 \\ \%\end{array} \\ \text { Total__a } & 12.3 & 12.2 \\ \text { Soluble_... } & 1.9 & 1.9\end{array}$

The values are high for both groups because of the inclusion of hair in the sample. The data show no change in sulfur content, and consequently no increased sulfuric acid content. It seems safe to assume that no acid deterioration has taken place in the skins.

\section{Effect of Copper and Iron on the Strength of the Leather}

Qualitative tests of the ash of the six groups of lamb furs showed the principal constituents, other than alkali salts, to be aluminum, iron, copper, and some phosphates. Aluminum probably constitutes the tanning agent, while the copper and iron are integral parts of the dyeing process.

Determinations of the amounts of these metals in the ash show that the ratio of each has not changed appreciably for dressings of each year. It would 
appear from the totals that the tanning and dyeing of the furs from year to year had not been changed to the extent of altering the characteristics of the pelts. The amounts found are shown in table 5 .

TABLE 5. Metallic constituents of ash (expressed in percentages of leather plus hair)

\begin{tabular}{|c|c|c|c|c|c|c|}
\hline \multirow{3}{*}{ Constituent } & \multicolumn{6}{|c|}{ Year of crop } \\
\hline & \multicolumn{4}{|c|}{ Group I } & \multicolumn{2}{|c|}{ Group II } \\
\hline & 1930 & 1931 & 1932 & 1933 & 1945 & $194 t$ \\
\hline $\begin{array}{l}\mathrm{Al}_{2} \mathrm{O}_{3} \\
\mathrm{Fe}_{2} \mathrm{O}_{3} \\
\mathrm{CuO}\end{array}$ & $\begin{array}{l}\% \\
1.06 \\
0.54 \\
.30\end{array}$ & $\begin{array}{l}\% \\
1.14 \\
0.63 \\
.22\end{array}$ & $\begin{array}{l}\% \\
0.82 \\
.57 \\
.32\end{array}$ & $\begin{array}{l}\% \\
0.67 \\
.69 \\
.34\end{array}$ & $\begin{array}{l}\% \\
0.89 \\
.65 \\
.14 \\
\end{array}$ & $\begin{array}{r}\% \\
0.81 \\
.78 \\
.18\end{array}$ \\
\hline Total. & 1.90 & 1.99 & 1.71 & 1.70 & 1.68 & 1.77 \\
\hline
\end{tabular}

The copper values differ significantly (at the 5percent level) between the two age groups. This may be meaningful. It has been postulated by a number of investigators that when copper and iron are present as impurities in vegetable-tanned leathers, deterioration is accelerated. Kanagy, ${ }^{1}$ in noting the lack of agreement in the conclusions of the investigators, conducted accelerated aging tests by exposing quebracho and chestnut-tanned leather impregnated with various salts of copper and iron, to an atmosphere of oxygen at $100 \mathrm{lb} / \mathrm{in}^{2}$ and $100^{\circ} \mathrm{C}$. His conclusions, in part, are as follows: All leathers containing added copper showed more deterioration than corresponding untreated leathers. Most of the deterioration occurs above $\mathrm{pH} 3$. The increase in the rate of deterioration with increasing copper content is most rapid for amounts less than 0.2 percent. At $\mathrm{pH}$ values above 3.5 , the effect of iron on the rate of deterioration is not appreciable. At lower $\mathrm{pH}$ values the deterioration appears to be a function of $\mathrm{pH}$ rather than iron content. For equal amounts of the metal added, that in the form of the sulfate was more active than that added as the acetate or lactate.

It is to be noted that the copper content for the strongest skins is less than that for the weaker skins. The content correlates fairly well with the yearly degradations.

The only physical test, as an indication of strength, made on the seal samples in 1939 was breaking strength. This property remeasured 10 years later on replicate samples was considerably lower, indicating deterioration during the storage period for both the brown and the black-dyed samples. Black-dyed pelts had lost more strength than brown-dyed pelts. Prior to storage, the pelts of both colors had approximately the same strength. Qualitative chemical analyses showed that the black dye was produced mainly with iron and copper salts, while the brown was achieved by the use of salts of tin, copper, chromium, and iron. Other metals were present in very small amounts in both varieties, but the magnitude of the amount did not justify quantitative analysis.

Comparison of available data, both physica! and

1 J. R. Kanagy, J. Am. Leather Chem. Assoc. 33, 352 (1938). chemical, of the Karakul and seal furs are shown in table 6.

TABLE 6. Comparison of Karakul and seal furs

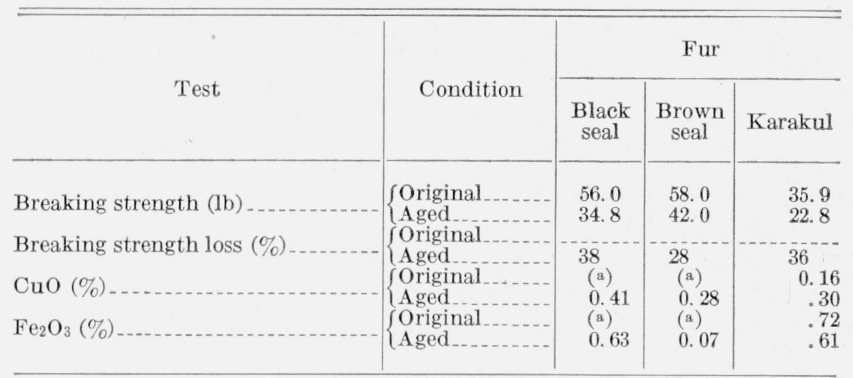

a Not determined.

The terms "original" and "aged" are used to describe the relative age levels of the furs. The original Karakuls were in storage approximately 5 years, while the original seal fur age was less than 1 year.

The three types of furs lost between 30 and 40 percent of their original strength after storage periods of approximately 10 years. Both Karakul and black seal furs contained considerable quantities of iron. The iron values of group I and group II of the lamb furs do not vary significantly. The quantity of iron found in the brown-dyed seal furs can hardly be considered the cause for the extent of deterioration that has occurred. The iron salts used in the dyeing, therefore, do not appear to be responsible in causing the breakdown of the pelts.

In each instance of comparison, higher copper values are associated with the greater losses of strength. It is concluded then that copper is instrumental in causing the deterioration. The quantities of the metal found in the skins suggest that its action is catalytic.

The deductions concerning the cause for the deterioration of the furs are in good agreement with the conclusions advanced by Kanagy, although the conditions of test and the materials used are quite different.

Kanagy's research involved accelerated aging by heat and pressure in the laboratory, while this study deals with naturally aged skins; his experiments were on vegetable-tanned heavy leather, quite unlike the light alum-and-oil-tanned skins studied in the present work; and copper was added to his leathers for the purpose of the investigation instead of being used as a normal ingredient in the dressing process, as was the case in this study.

So far as is known, this study is the first in which cataly tic degradation of oil- or alum-tanned skins by copper has been indicated.

Since the copper percentages of the seal skins are higher than the percentages in the lambskins, a greater extent of deterioration might also have been expected. This need not necessarily be so, as the dye coloring matter, in the case of the seal furs, was applied only to the fur portion, while the lambskins appear to have been dip-dyed. By dip-dyeing more 
copper would be distributed on the leather than, would be if the dye bath was applied only to the fur surface.

Another reason the seal fur did not deteriorate as much as might be expected from the copper content, as compared to the Karakuls, may be that the oil tannage is inherently more resistant than the predominantly alum-type dressing of the lambskins.

The rate with which the metal salts are leached or removed from the lambskin pelts holds no relationship to the extent of deterioration. In other words the degree of the fixation of metal salts does not follow the aging. The results of water extraction of the metal salts from the skins are shown in table 7 .

\section{Summary}

Aged crossbred Karakul lamb furs appear to have different physical properties than aged purebred Karakul lamb furs.

Purebred Karakul lamb furs in storage 15 years or more are considerably weaker in strength than similar pelts in storage approximately 4 years. Differences in strength between the age groups are not attributed to a change in tannage procedure over the consecutive years of processing.

Comparable losses in strength occurred in Alaskan seal furs after a storage period of 10 years.

Evidences of acid deterioration were not found.

The presence of small quantities of copper salts, which are introduced into the furs during dyeing, relates significantly with the extents of deterioration, and provides evidence that the metal acting cata-
TABLE 7. Aluminum, iron, and copper content of watersoluble extractives

\begin{tabular}{|c|c|c|c|c|c|c|}
\hline \multirow{3}{*}{ Constituent } & \multicolumn{6}{|c|}{ Year of crop } \\
\hline & \multicolumn{4}{|c|}{ Group I } & \multicolumn{2}{|c|}{ Group II } \\
\hline & 1930 & 1931 & 1932 & 1933 & 1945 & 1946 \\
\hline $\begin{array}{l}\mathrm{Al}_{2} \mathrm{O}_{3--} \\
\mathrm{Fe}_{2} \mathrm{O}_{3 .-} \\
\mathrm{CuO}\end{array}$ & $\begin{array}{r}\text { Percent } \\
0.387 \\
.006 \\
.065\end{array}$ & $\begin{array}{r}\text { Percent } \\
0.129 \\
.007 \\
.006\end{array}$ & $\begin{array}{r}\text { Percent } \\
0.290 \\
.046 \\
.030\end{array}$ & $\begin{array}{r}\text { Percent } \\
0.112 \\
.020 \\
.012\end{array}$ & $\begin{array}{r}\text { Percent } \\
0.295 \\
.080 \\
.058\end{array}$ & $\begin{array}{c}\text { Percent } \\
0.165 \\
.030 \\
.010\end{array}$ \\
\hline Total & 0.458 & 0.142 & 0.366 & 0.144 & 0.433 & 0.205 \\
\hline
\end{tabular}

lytically promotes deterioration. Iron salts apparently do not promote deterioration appreciably.

The findings are in accord with a previously published report on the influence of copper and iron on vegetable-tanned leather deteriorated under accelerated conditions. The findings are novel in that the leathers described herein were of an alum or oil tannage, which were aged under normal shelf storage conditions.

The extents of deterioration are conveniently measured by determining either burst, breaking strength, or stitch tear (furrier-sewn) values. Losses in strength are accompanied by lower petroleum ether extractives, increased water solubles, increased soluble proteinaceous and other water-extractable organic matter.

Washington, June 19, 1950.

\title{
Second Dissociation Constant of Succinic Acid from $\mathrm{O}^{\circ}$ to $50^{\circ} \mathrm{C}$
}

\author{
By Gladys D. Pinching and Roger G. Bates
}

\begin{abstract}
The second dissociation constant of succinic acid at intervals of 5 degrees from $0^{\circ}$ to $50^{\circ}$ $\mathrm{C}$ was determined from measurements of the electromotive force between hydrogen and silver-silver chloride electrodes in cells without liquid junction. The 19 solutions studied were divided into two series. The first series was made up of aqueous mixtures of sodium acid succinate, sodium succinate, and sodium chloride in the molar proportions $1: 3: 3$. The solutions of the second series contained only sodium acid succinate and sodium chloride, in the molar ratio $1: 1$. The measurements of the second series were used to compute an approximate value for the first dissociation constant of the acid to be employed in correcting the results of the first series for the amount of free succinic acid formed by hydrolysis. by

The second dissociation constant, $K_{2}$, for the temperature range studied can be expressed
\end{abstract}

$$
-\log K_{2}=1679.13 / T-5.7043+0.019153 T \text {, }
$$

where $T$ is the temperature on the Kelvin scale. Thermodynamic quantities for the dissociation of acid succinate ion were calculated from the temperature coefficient of the second dissociation constant. At $25^{\circ} \mathrm{C}$, the standard free-energy change was found to be 32,182 abs $j$ mole $^{-1}$, and the changes of heat content and entropy for the dissociation process in the standard state were -450 abs $j$ mole $^{-1}$ and -109.4 abs $j \mathrm{deg}^{-1} \mathrm{~mole}^{-1}$, respectively.

\section{Introduction}

The simultaneous dissociation of two or more acid groups of nearly equal strength complicates the determination of the dissociation constants of many dibasic and polybasic organic acids. Accurate values may indeed be impossible to obtain when the degree of dissociation is large in each overlapping step. Consequently, the thermodynamic quantities, such as heat-content and entropy changes, associated 